\title{
Perancangan dan Analisis Antena Dipole pada Frekuensi 2,4 GHz untuk Modul Xbee S2 Pro Menggunakan HFFS 14.0
}

\author{
Shinta Romadhona ${ }^{1 *}$, Diana Alia ${ }^{2)}$, Maya Zulfida ${ }^{3)}$ \\ 1,3) Departemen Teknik Telekomunikasi dan Elektro, Institut Teknologi Telkom, Purwokerto \\ ${ }^{2)}$ Prodi Elektro Pelayaran, Politeknik Pelayaran, Surabaya \\ *email:shinta@ittelkom-pwt.ac.id
}

\begin{abstract}
Xbee s2 pro module works at 2,4 Ghz using IEEE 802.15.4 standard and polarization are linear. There are many types of antennas that can be used, which one is the dipole antenna. The simulation model implemented in this study uses Ansoft HFSS 14.0 software. HFSS stands for high frequency structure simulator is a pioneer in the use of finite element method for electromagnetic wave simulators that implement tangential vector finite elements, adaptive meshing and Adaptive Lanczos-Pade Sweep (ALPS) technology. By using HFSS 14.0 simulation, the axial ratio value of $35.0359 \mathrm{~dB}$ that means linier polarization. For the value of s-parameter -21,1851 db and VSWR value approaches 1, that is $1.5195 \mathrm{db}$. The gain value obtained is $0.7469 \mathrm{~dB}$, the gain value needs to be optimized by using a metamaterial to get a good gain.
\end{abstract}

Keywords — Dipole Antenna, Xbee S2 Pro, HFSS 14.0

\section{Pengantar}

Jaringan tanpa kabel ini berkembang sangat pesat dengan memanfaatkan daya jangkau sinyal yang besar dalam ruangan, menjadi salah satu alasan kenapa teknologi indoor positioning banyak digunakan[1]. Salah satu perangkat yang dapat mendukung teknologi indoor positioning yaitu Xbee S2 Pro. Xbee S2 Pro dikarenakan memiliki beberapa keunggulan yaitu (Wi-Fi) lebih andal dan terhindar dari interferensi.

Xbee S2 Pro merupakan salah satu jenis Xbee yang diproduksi dari Digi International. Keunggulan Xbee S2 Pro yaitu memiliki daya yang lebih besar dan jangkauan komunikasinya lebih luas. Xbee S2 Pro merupakan radio frequency transceiver atau modul yang terdiri dari RF receiver dan RF transmitter yang berfungsi sebagai protokol komunikasi nirkabel. Modul Xbee S2 Pro bekerja pada frekuensi $2.4 \mathrm{GHz}$ dengan menggunakan standar IEEE 802.15.4. Modul ini dapat menyajikan kemampuan untuk pengiriman data antar perangkat dengan kemampuan yang bervariasi tergantung pada kondisi dan tempat[2].

Modul Xbee S2 Pro memiliki tipe antena menggunakan tipe chip antena. Hal tersebut dikarenakan tipe chip antena memiliki jarak jangkauan indoor yang lebih luas dibanding dengan tipe chip antena. Antena chip merupakan suatu antena berbentuk chip yang teletak pada board modul Xbee S2 Pro. Berdasarkan datasheet Xbee S2 Pro, antena tersebut memiliki polarisasi linier[3].

Antena adalah elemen penting yang ada pada setiap sistem telekomunikasi tanpa kabel (nirkabel/wireless), tidak ada sistem telekomunikasi wireless yang tidak memiliki antena. Pemilihan antena yang tepat, perancangan yang baik dan pemasangan yang benar akan menjamin kinerja sistem tersebut. Antena merupakan sebuah komponen yang dirancang untuk bisa memancarkan dan atau menerima gelombang elektromagnetika[4]. Suatu antena dikatakan berpolarisasi linier jika arah medan elektrik memiliki arah yang tetap sepanjang

Manuscript submitted 24 September 2019; revised 20 January 2020; accepted 21 January 2020. Published 21 January 2020; http://dx.doi.org/10.28989/avitec.v2i1.535 
waktu dan di semua posisi. Antena terpolarisasi linier dibagi menjadi, 2 yaitu vertikal dan horizontal. Jika suatu antena penerima memiliki polarisasi linier, maka antena ini hanya dapat menerima sinyal dari antena dengan polarisasi vertikal atau horizontal. Keunggulan dari antena dipole yaitu memiliki struktur yang sederhana dan berdimensi kecil. Maka diperlukan perancangan antenna dipole yang dapat meningkatkan jangkauan pada frekuensi $2,4 \mathrm{GHz}$ dengan menggunakan software Ansoft HFFS 14.0 dari antena chip yang telah ada pada. Melalui parameter-parameter antena maka diharapkan antena dapat beroperasi pada frekuensi yang diinginkan.

\section{Dasar Teori}

\subsection{Gain}

Gain merupakan salah satu parameter yang berfungsi untuk memperhitungkan efisiensi antena. Gain antena (dalam arah tertentu) didefinisikan sebagai "rasio intensitas dalam arah yang diberikan dengan intensitas radiasi yang akan diperoleh jika daya diterima oleh antena yang dipancarkan isotropik[5].

Dalam berbagai kasus, sering dijumpai relative gain, yang didefinisikan sebagai "rasio power gain dalam arah tertentu untuk power gain antena referensi dalam arah yang direferensikan". Input daya harus sama untuk kedua antena. Dalam kebanyakan kasus, antena referensi adalah sumber isotropik lossless. Nilai gain dapat dihitung menggunakan Persamaan (1)[5].

$$
G=\frac{4 \pi U(\theta, \phi)}{P_{\text {in }}(\text { lossless isotropic source })}
$$

$$
\begin{aligned}
\operatorname{Dimana} G & =\text { gain } \\
P_{\text {in }} & =\text { total daya input } \\
U(\theta, \phi) & =\text { intensitas radiasi }
\end{aligned}
$$

\subsection{VSWR (Voltage Standing Wave Ratio)}

VSWR merupakan pengukuran dasar dari impedansi matching antara transmitter dan antena. Rumus untuk mencari nilai VSWR mengikuti Persamaan (2)[6].

$$
V S W R=\frac{1+|\Gamma|}{1-|\Gamma|}
$$

Dimana $\Gamma=$ Koefisien pantul

Dari persamaan di atas besarnya koefisien pantul menentukan besarnya VSWR. Rumus untuk mencari nilai koefisien pantul mengikuti Persamaan (3)[6].

$$
\Gamma=\frac{V_{r}}{V_{i}}=\frac{Z_{\text {in }}-Z_{s}}{Z_{\text {in }}-Z_{s}}
$$

Dimana $V_{0}^{-}=$Tegangan gelombang pantul (reflected wave)

$V_{0}^{+}=$Tegangan gelombang maju (incident wave)

$Z_{\text {in }}=$ Impedansi beban (load)

$Z_{s}=$ Impedansi saluran 
Nilai VSWR yang baik adalah 1, yang artinya tidak ada refleksi. Hal ini terjadi ketika saluran dalam keadaan matching sempurna. Namun untuk mendapatkan VSWR yang bernilai 1 itu sangatlah sulit, sehingga nilai VSWR ditoleransi menjadi kurang dari 2. Semakin tinggi nilai VSWR maka semakin besar pula mismatch dan semakin rendah VSWR maka antena semakin matching[6].

\subsection{Return Loss}

Return loss merupakan salah satu parameter yang digunakan untuk mengetahui berapa banyak daya yang hilang pada beban dan tidak kembali. Fungsi return loss juga sama seperti VSWR yaitu untuk menentukan matching antara antena dan transmitter. Rumus untuk mencari nilai return loss sebagaimana Persamaan (4) [6].

$$
\text { return loss }=20 \log _{10}|\Gamma|
$$

Antena yang baik akan mempunyai nilai return loss di bawah -10 dB, yaitu $90 \%$ sinyal yang diserap dan $10 \%$ yang dipantulkan kembali[6].

\subsection{Axial Ratio}

Salah satu syarat untuk membuat polarisasi circular yaitu axial ratio (AR). Axial ratio merupakan perbandingan major axis (OA) dengan minor axis (OB) [5]. Nilai axial ratio menjadi salah satu acuan untuk melihat apakah antena yang dibuat berpolarisasi linier, circular atau elips. Axial ratio ini dapat diperoleh dengan persamaan (5).

$$
A R=\frac{\text { major axis }}{\text { minor axis }}=\frac{O A}{O B}
$$

Dimana :

$\mathrm{OA}=$ major axis

$\mathrm{OB}=$ minor axis

Tahap penentuan spesifikasi ini berfungsi agar antena yang disimulasikan memiliki nilai standar yang harus dipenuhi. Pada penelitian ini, antena yang akan dirancang adalah antena dipole yang memiliki spesifikasi:

$\begin{array}{ll}\text { Frekuensi kerja } & : 2.4 \mathrm{GHz} \\ \text { S-parameter } & :<-10 \mathrm{~dB} \\ \text { VSWR } & :<2 \mathrm{~dB} \\ \text { Gain } & :>5 \mathrm{~dB}\end{array}$

\section{Metodologi}

Penelitian ini menggunakan simulasi untuk disesuaikan dengan input dari modul Xbee S2 Pro. Model simulasi yang diimplementasikan dalam penelitian ini menggunakan perangkat lunak Ansoft HFSS 14.0. HFSS singkatan dari High Frequency Structure Simulator adalah pelopor penggunaan metode elemen terbatas (Finite Elemen Method) untuk simulator gelombang EM yang mengimplementasikan teknologi tangetial vector finite elements, adaptive meshing dan adaptive lanczos-Pade Sweep (ALPS). Ansoft HFSS adalah suatu simulator medan elektromagnetik untuk pemodelan 3 dimensi perangkat pasif berstruktur frekuensi tinggi yang memiliki kelebihan sangat mudah dan interaktif digunakan pada sistem operasi microsoft grafical user interface. Dalam simulatornya terintegrasi visualisasi, pemodelan volumetrik dan kemudahan dalam interaktif di mana solusi permasalahan 
pemodelan 3 dimensi bisa cepat dan akurat didapatkan. Ansoft HFSS dapat digunakan untuk mengalkulasi beberapa parameter di antaranya yaitu parameter $\mathrm{S}$ dan medan elektromagnetika[7]. Penelitian ini dilakukan mengikuti diagram alir pada Gambar 1.

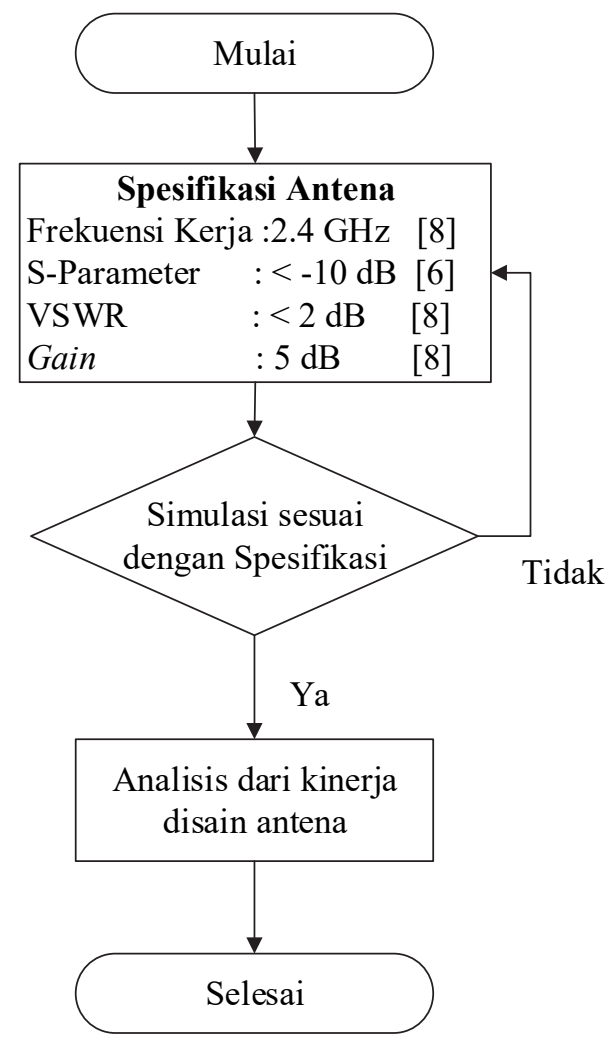

Gambar 1. Diagram Alir Penelitian Antena Dipole

\subsection{Antena Dipole}

Antena memiliki transduser antara pengendali gelombang propagasi pada saluran transmisi dan gelombang propagasi elektromagnetik pada keadaan free space. Pada arus antena linear dipole pendek memperhitungkan kesamaan panjang suatu elemen. Ini data dilihat dari medan magnet dan medan elektrik yang diradiasikan pada dipole pendek panjang elemen (l) harus lebih kecil dari $\lambda[9]$.

Pada tahap ini, ukuran dimensi antena akan mempengaruhi karakteristik antena yang akan dibuat. Tahap-tahap perhitungan dimensi antena dipole seperti menentukan panjang gelombang dan panjang antena dipole. Sebelum menentukan panjang antena dipole, terlebih dahulu harus ditentukan panjang gelombang karena panjang antena dipole berkaitan dengan panjang gelombang. Untuk menghitung panjang gelombang dapat menggunakan persamaan (6)[5].

$$
\lambda=\frac{c}{f}
$$

$$
\text { Dimana } \begin{aligned}
\lambda & =\text { panjang gelombang }(\mathrm{mm}) \\
\mathrm{c} & =\operatorname{kecepatan} \text { cahaya }(\mathrm{m} / \mathrm{s}) \\
f & =\text { frekuensi kerja }(\mathrm{Hz})
\end{aligned}
$$


Pada penelitian ini, $\lambda=\frac{3 \times 10^{8}}{2,4 \times 10^{9}}=0,125 \mathrm{~m}=125 \mathrm{~mm}$.

Daya radiasi rata-rata dari antena dipole dapat diketahui dari far field dari antena dipole. Kegunaan dari antena dalam komunikasi dapat berfungsi dengan baik dari far filed. Daya radiasi dapat ditentukan menggunakan Persamaan (7)[10].

$$
P_{\text {rad }}=\oint S_{a v} \bullet d_{s}
$$

Dimana:

$P_{\text {rad }}=$ Daya Radiasi

$S_{a v}=$ kerapatan daya rata-rata

$d_{s} \quad=$ Radius bola yang terpusat $\mathrm{r}$

\subsection{Perancangan Model Antena Dipole Pada Ansoft HFSS}

Pada perancangan antena ini menggunakan perangkat lunak Ansoft HFSS versi 14 berdasarkan dimensi antena yang diperoleh dari perhitungan diatas. Perancangan yang pertama kali dibuat yaitu antena dipole. Perancangan antena bertujuan untuk mengetahui seberapa bagus performansi antena tersebut dan hasil dari antena tersebut sudah sesuai dengan spesifikasi yang telah ditentukan atau belum. Pada Gambar 2 ditampilkan desain antena dipole.

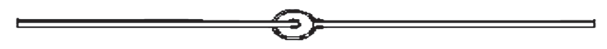

Gambar 2. Desain Awal Antena Dipole

Dari perancangan antena dipole menggunakan perangkat lunak Ansoft HFSS 14 didapatkan hasil simulasi seperti axial ratio, gain dan s-parameter yang dapat dilihat pada Tabel 1.

Tabel 1. Hasil Simulasi Antena Dipole

\begin{tabular}{c|c}
\hline Parameter & Nilai \\
\hline Axial Ratio & $48,4558 \mathrm{~dB}$ \\
\hline Gain & $0,5071 \mathrm{~dB}$ \\
\hline S-Parameter & $-13,9845 \mathrm{~dB}$ \\
\hline VSWR & 3,5197 \\
\hline
\end{tabular}

\section{Hasil Penelitian dan Analisa}

\subsection{Parameter Penelitian}

Parameter yang perlu diperhatikan dalam penelitian ini yaitu axial ratio, s-parameter, vswr dan gain. Axial ratio adalah parameter yang berfungsi untuk melihat apakah antena yang dibuat berpolarisasi circular, linier atau elips adalah parameter yang berfungsi untuk menggambarkan daya yang dipancarkan oleh antena, s-parameter merupakan parameter yang berfungsi untuk mengetahui seberapa banyak daya yang hilang dan tidak kembali. Nilai axial ratio dapat dilihat pada Gambar 3. 


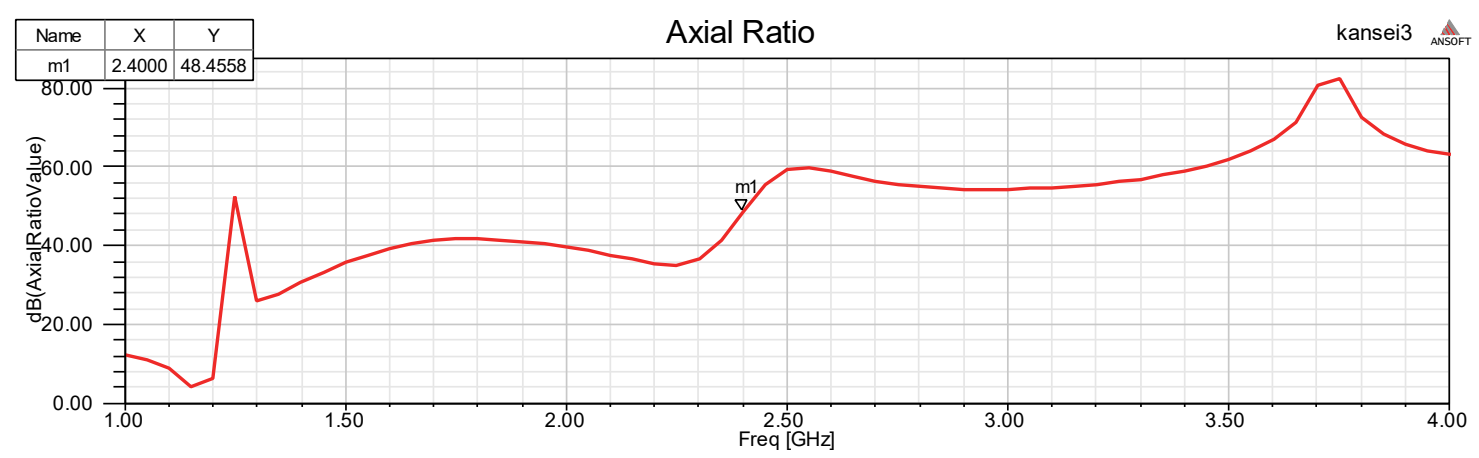

Gambar 3. Axial Ratio Antena Dipole

Dari Gambar 3 dapat dilihat bahwa nilai axial ratio pada frekuensi 2,4 $\mathrm{GHz}$ yaitu $48,4558 \mathrm{~dB}$. Nilai ini menyatakan bahwa antena dipole ini memiliki polarisasi linier. Grafik gain antena dipole ini dapat dilihat pada Gambar 4.

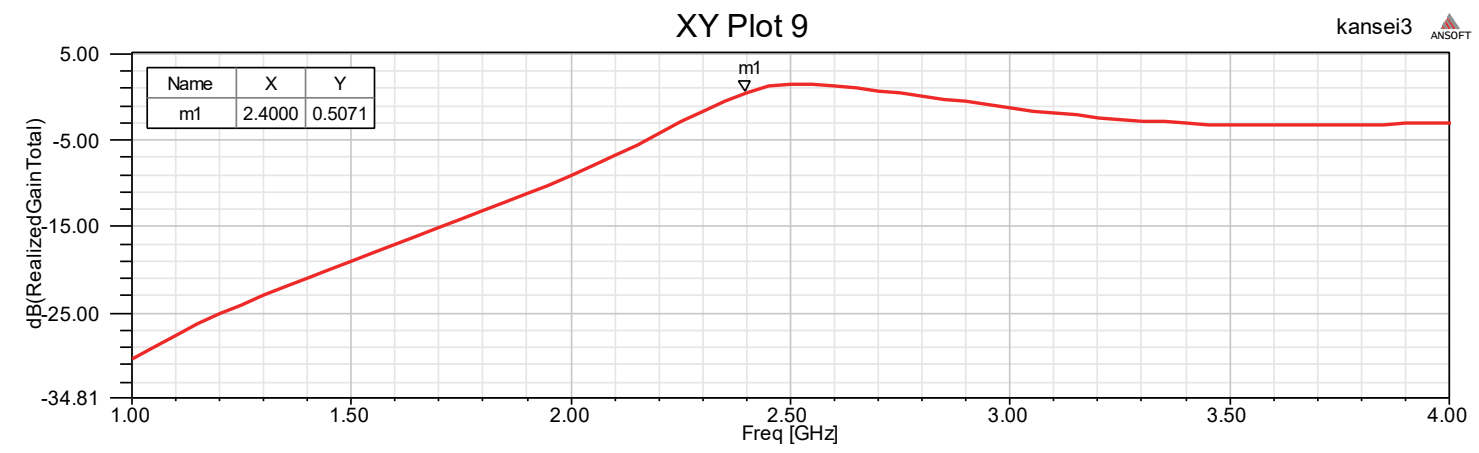

Gambar 4. Gain Antena Dipole

Dari Gambar 4 dapat dilihat bahwa nilai gain untuk frekuensi 2,4 GHz yaitu 0,5071 dB. Nilai tersebut masih belum memenuhi spesifikasi yang telah ditentukan karena nilainya masih kurang dari $5 \mathrm{~dB}$.

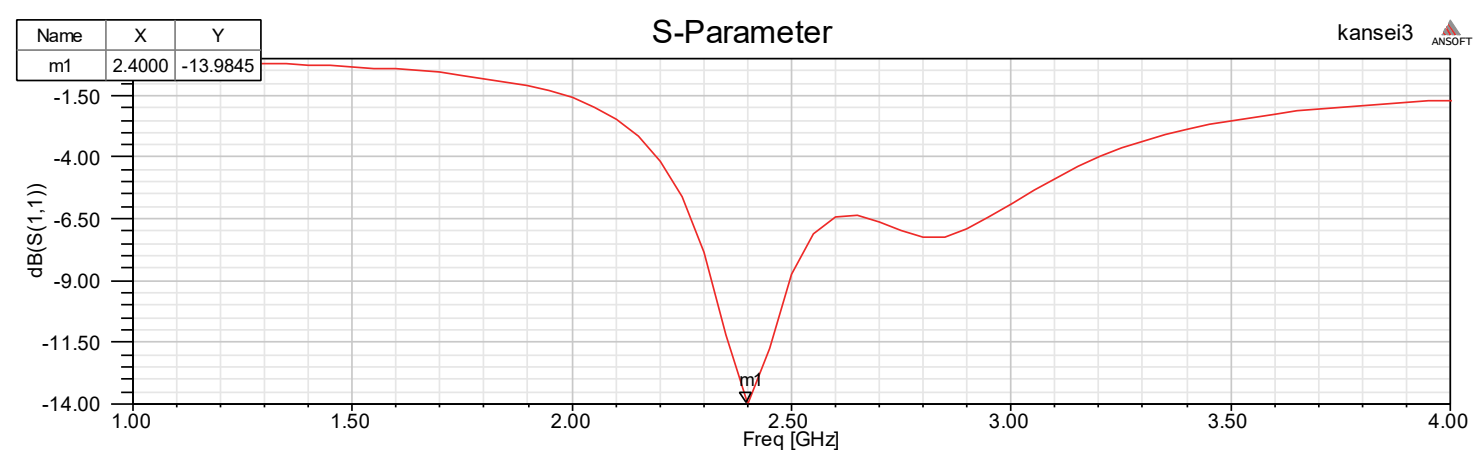

Gambar 5. S-Parameter Antena Dipole

Dari Gambar 5 dapat dilihat bahwa nilai s-parameter pada frekuensi 2,4 GHz menjadi $-3,9845 \mathrm{~dB}$. Nilai tersebut sesuai spesifikasi yang telah ditentukan karena nilainya kurang dari $-10 \mathrm{~dB}$. 


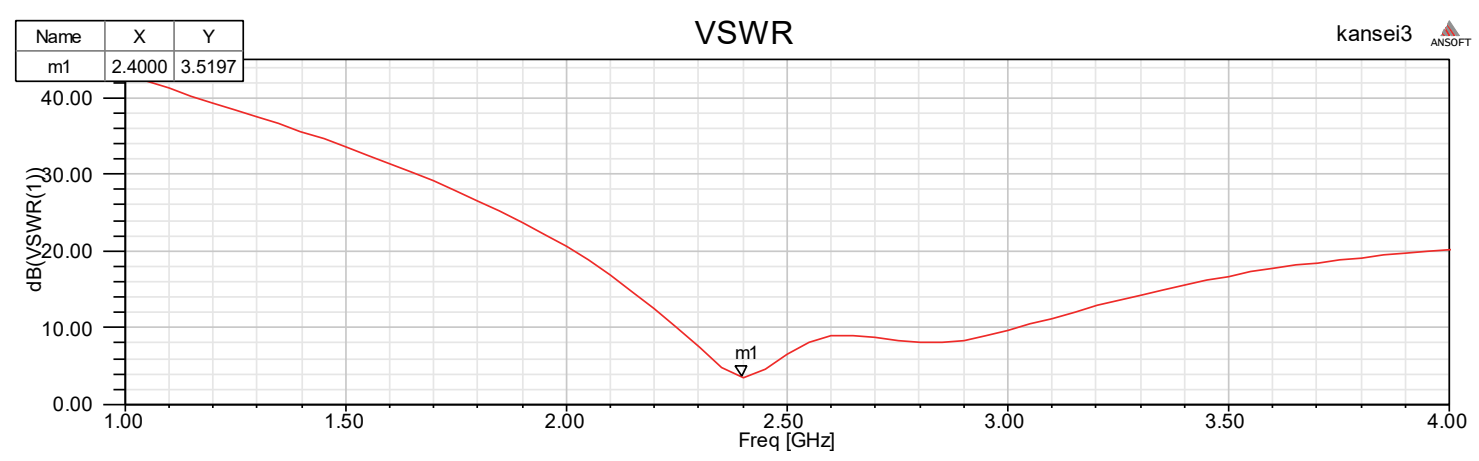

Gambar 6. VSWR Antena Dipole

Untuk nilai VSWR dari Gambar 6 adalah 3,5197dB. Nilai ini masih belum optimal dari VSWR yang diinginkan yaitu kurang dari $2 \mathrm{~dB}$.

\subsection{Hasil Penelitian}

Berdasarkan hasil simulasi di atas dapat disimpulkan bahwa antena dipole ini ternyata hasilnya masih belum sesuai dengan spesifikasi yang telah ditentukan. Untuk itu harus dilakukan perbaikan supaya menghasilkan nilai yang sesuai dengan spesifikasi antena yang telah ditentukan yaitu dengan cara mempertinggi outer conductor dari $0.05 \mathrm{~mm}$ sampai 0.3 $\mathrm{mm}$ dengan rentang $0.05 \mathrm{~mm}$ tiap perubahan tingginya. Hasil perubahan tinggi outer conductor dapat dilihat pada Tabel 2.

Tabel 2. Hasil Perubahan Tinggi Outer Conductor

\begin{tabular}{c|c|c|c|c}
\hline $\begin{array}{c}\text { Tinggi } \\
\begin{array}{c}\text { Outer Conductor } \\
(\mathrm{mm})\end{array}\end{array}$ & $\begin{array}{c}\text { Axial Ratio } \\
(\mathrm{dB})\end{array}$ & $\begin{array}{c}\text { Gain } \\
(\mathrm{dB})\end{array}$ & $\begin{array}{c}\text { S-Parameter } \\
(\mathrm{dB})\end{array}$ & $\begin{array}{c}\text { VSWR } \\
(\mathrm{dB})\end{array}$ \\
\hline 0,05 & 30,0252 & 0,5171 & $-22,3186$ & 1,3328 \\
\hline 0,10 & 41,5825 & 0,5557 & $-21,9226$ & 1,3952 \\
\hline 0,15 & 36,9154 & 0,5218 & $-24,2127$ & 1,0709 \\
\hline 0,20 & 36,9912 & 0,7078 & $-22,7815$ & 1,2634 \\
\hline 0,25 & 36,2455 & 0,5523 & $-23,6247$ & 1,1461 \\
\hline 0,30 & 35,6952 & 0,5934 & $-24,6153$ & 1,0223 \\
\hline
\end{tabular}

Setelah dilakukan perubahan outer conductor, didapatkanlah hasil yang terbaik dari perubahan yaitu pada tinggi $0,15 \mathrm{~mm}$. Tetapi karena nilainya masih belum sesuai dengan spesifikasi yang telah ditentukan. Maka dilakukan perubahan dengan tinggi wire dari $3 \mathrm{~mm}$ sampai $4 \mathrm{~mm}$. Hasil perubahan tersebut dapat dilihat pada Tabel 3. 
Tabel 3. Hasil Perubahan Tinggi Wire

\begin{tabular}{c|c|c|c|c}
\hline $\begin{array}{c}\text { Tinggi Wire } \\
(\mathrm{mm})\end{array}$ & $\begin{array}{c}\text { Axial Ratio } \\
(\mathrm{dB})\end{array}$ & $\begin{array}{c}\text { Gain } \\
(\mathrm{dB})\end{array}$ & $\begin{array}{c}\text { S-Parameter } \\
(\mathrm{dB})\end{array}$ & $\begin{array}{c}\text { VSWR } \\
(\mathrm{dB})\end{array}$ \\
\hline 3 & 36,9154 & 0,5218 & $-24,2127$ & 1,0709 \\
\hline 3.2 & 35,0359 & 0,7469 & $-21,1851$ & 1,5195 \\
\hline 3,5 & 38,3891 & 0,9181 & $-16,2508$ & 2,6963 \\
\hline 4 & 41,7418 & 1,1779 & $-10,9219$ & 5,0803 \\
\hline
\end{tabular}

Setelah dilakukan perubahan tinggi wire, didapat hasil yang terbaik dari perubahan yaitu pada tinggi $3,2 \mathrm{~mm}$. Untuk lebih jelasnya nilai parameter dilihat pada Gambar 7.

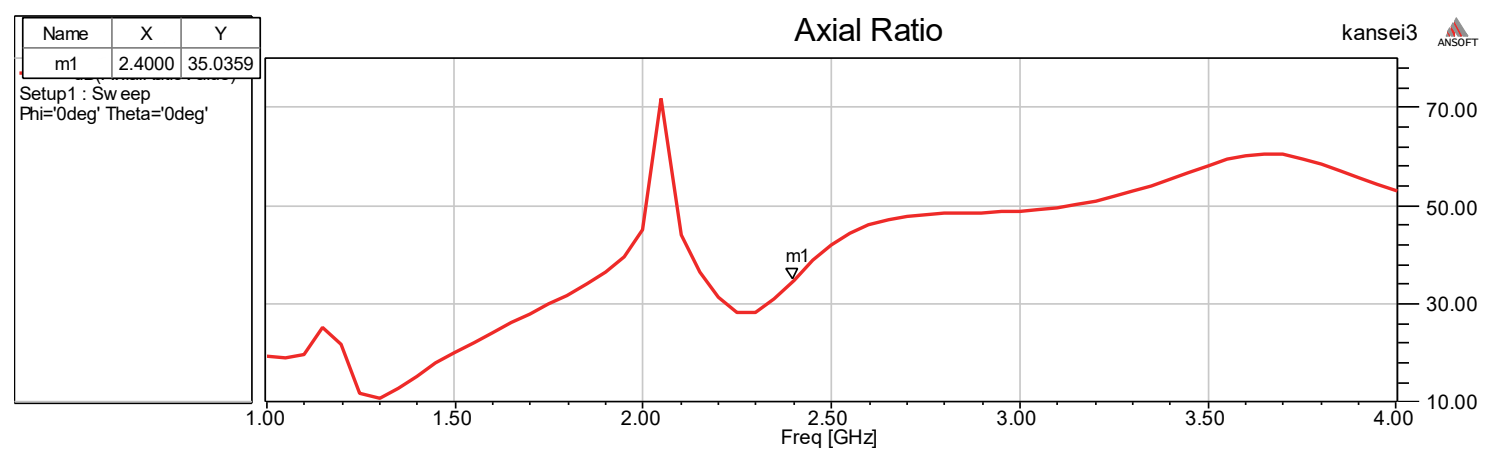

Gambar 7. Axial Ratio Antena Dipole dengan Tinggi Wire 3,2 mm, Tinggi Outer Conductor $0,15 \mathrm{~mm}$

Dari Gambar 7 didapat nilai axial ratio pada frekuensi 2,4 GHz yaitu 35,0359 dB. Dengan nilai axial ratio 35,0359 dB tersebut menunjukkan bahwa antena dipole tersebut memiliki polarisasi linier.

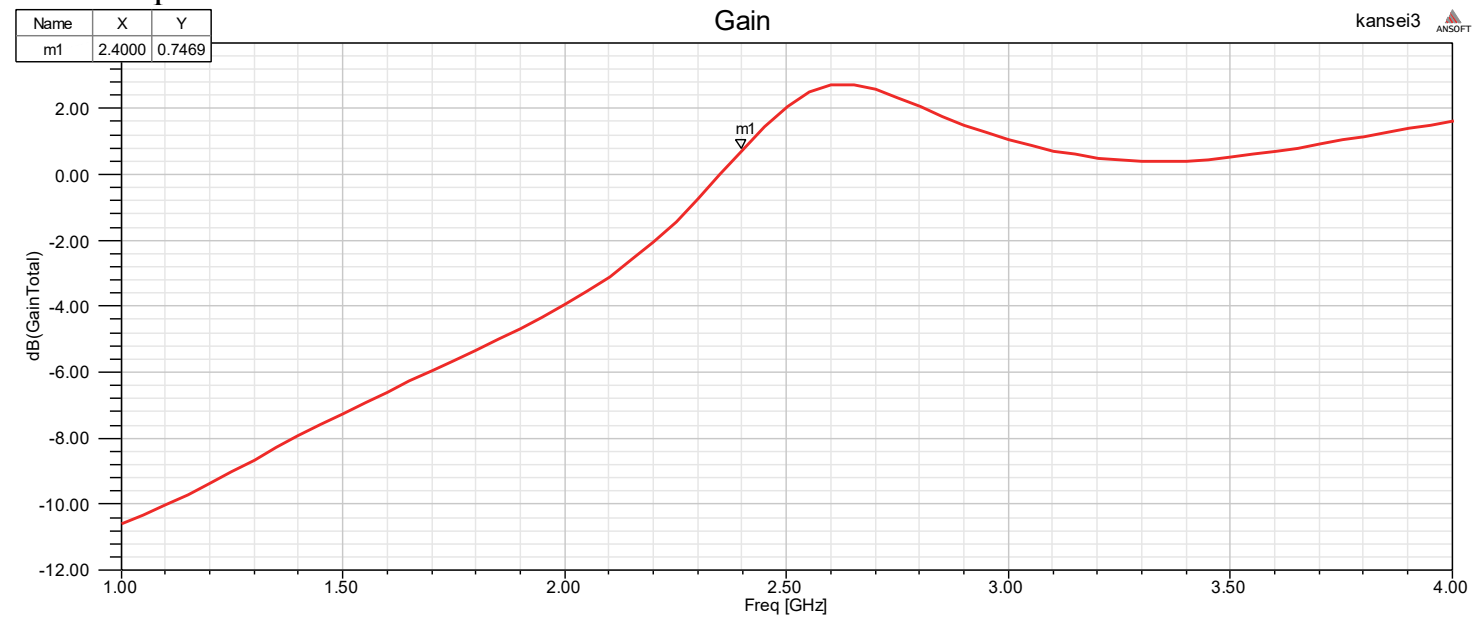

Gambar 8. Gain Antena dipole dengan tinggi wire 4,8 mm, tinggi Outer Conductor 0,1 mm

Dari Gambar 8 nilai gain pada frekuensi 2,4 GHz yaitu 0,7469 dB. Nilai tersebut belum dapat dikatakan bagus karena nilainya masih kurang dari spesifikasi yang telah ditentukan yaitu $5 \mathrm{~dB}$. 


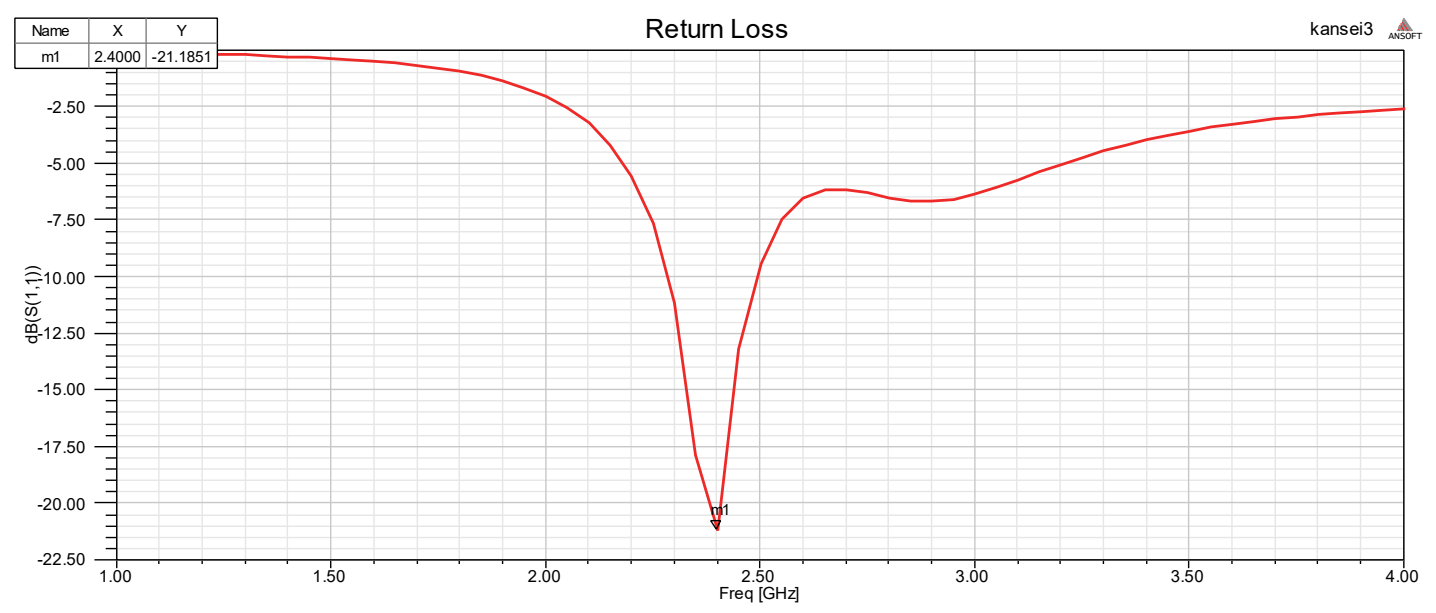

Gambar 9. Return Loss Antena Dipole dengan Tinggi Wire 3,2 mm, Tinggi Outer Conductor $0,15 \mathrm{~mm}$

Dari Gambar 9 nilai s-parameter pada frekuensi 2,4 GHz yaitu $-21,1851 \mathrm{~dB}$. Nilai tersebut sudah memenuhi spesifikasi yang telah ditentukan karena nilainya masih lebih dari $10 \mathrm{~dB}$.

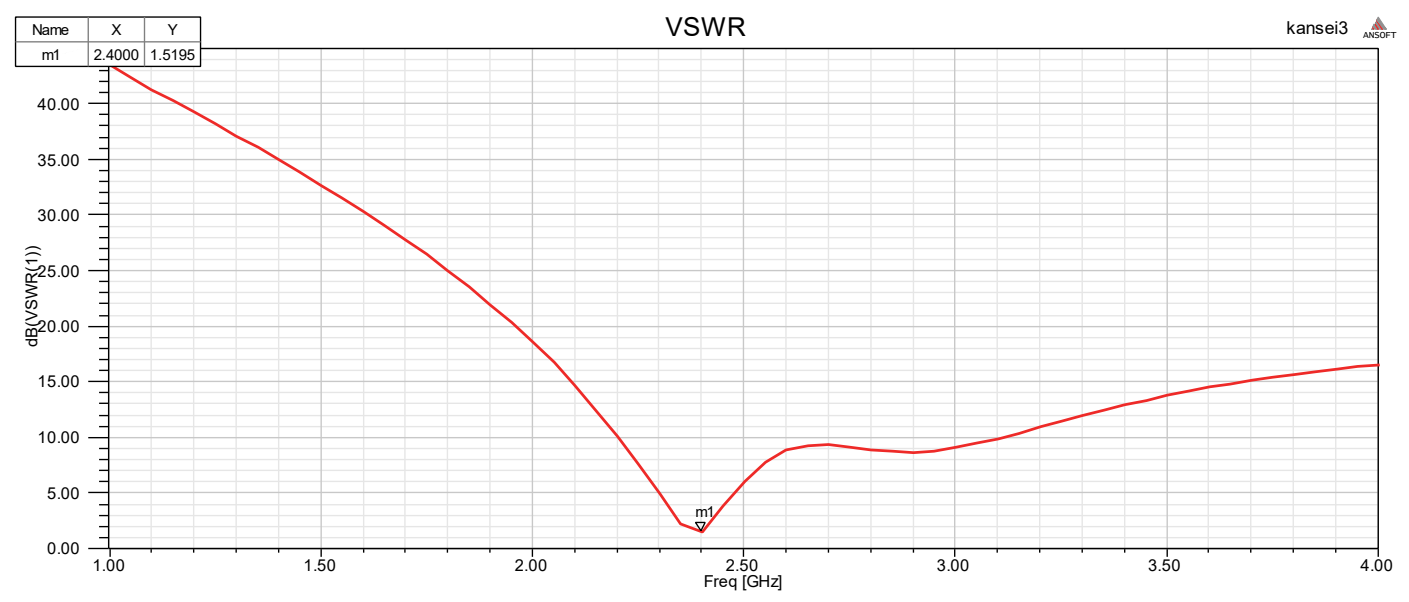

Gambar 10. VSWR Antena Dipole dengan tinggi Wire 3,2 mm, tinggi Outer Conductor $0,15 \mathrm{~mm}$

Dari Gambar 10 diketahui pada frekuensi 2,4 GHz didapat nilai VSWR yaitu 1,515 $\mathrm{dB}$. Nilai ini sudah dikatakan baik karena telah sesuai dengan parameter yang diinginkan yaitu kurang dari $2 \mathrm{~dB}$.

\section{Kesimpulan}

Berdasarkan pembahasan mengenai perancangan dan analisis antena dipole pada frekuensi 2,4 GHz untuk modul Xbee S2 pro dengan menggunakan HFFS 14.0 diperoleh nilai axial ratio 35,0359 dB, nilai s-parameter $-21,1851 \mathrm{~dB}$, nilai VSWR 1,5195 dB tetapi nilai gain hanya mencapai $0,7469 \mathrm{~dB}$. Dengan demikian hanya nilai gain yang belum memenuhi spesifikasi $5 \mathrm{~dB}$. 


\section{Daftar Pustaka}

[1] Ginting, T., \& Warasto, D. (2014). Penentuan Lokasi Objek Indoor Dengan Kekuatan Sinyal Yang Diterima Oleh Wireles Lan. Politeknosains. vol. XIII, Indoor Positioning, pp. 46-47.

[2] Kristalina, P. Modu; Praktikum Jaringan Telekomunikasi 2 Komunikasi Nirkabel menggunakan Modul RF X-Bee, Available: http://prima.lecturer.pens.ac.id/Siskomnir/ Modul 1.pdf.

[3] Dinata, \& Marta, T. (2015). Rancang Bangun Wireless Remote Sensing Sistem untuk Memantau Temperature dengan Menggunakan Protokol ZigBee. JUISI, vol. I, Xbee Series 2 Chip Antenna dan Xbee Pro Series 2 Wire Antenna, p. 87.

[4] Alaydrus \& Mudrik. (2011). Antena Prinsip \& Aplikasi. Yogyakarta: Graha Ilmu

[5] Balanis, \& Constantine,A. (2008). Modern Antenna Handbook. United States of America: A John Wiley \& Sons, Inc.

[6] Yuwono, R., Julianto L., Choiron, M. A., \& Anindito, P. (2007). Perancangan Dimensi Antena Ultra Wide Band (Rugby Ball)Yang Paling Efektif Untuk Monostatic Microwave Radar. Tekno, vol. VIII, VSWR dan Return Loss, pp. 2-3.

[7] Tanansyah, F., Ansini P., \& Ibnutoto, S. 24 Jam Mahir Ansoft. Jakarta Selatan: ISTN.

[8] Digi. (2018) Zigbee RF Modules User Guide. United States: Digi International.

[9] Clayton R. Paul., Syed A. Nasar. (1992). Introduction Electromagnetic Fields. Singapore: Fong \& Sons Printers, McGraw-Hill International Editions.

[10] Fawwaz T. Ulaby. (2001). Fundamental Of Applied Electromagnetics 2001 Media Edition. Prentice Hall. 